\title{
Linguistic Barriers in Online Teaching at Undergraduate Level in the University of
}

\author{
Malakand Pakistan \\ * Zaheer Ullah, Lecturer \\ ** Shaukat Ali, Assistant Professor (Corresponding Author) \\ *** Saddam Hussain, Lecturer
}

\begin{abstract}
Language plays a central role in the teaching-learning process. Without language, teaching can never happen; whether it is face-to-face or online teaching. With the outbreak of covid-19, teaching switched over from face-to-face to online one for the first time. Often, in online teaching linguistic barriers occur, since the teacher is not physically present in the classroom to clarify certain situations. This paper attempts to find out various linguistic barriers that occurred in online teaching at the undergraduate level at the University of Malakand. The researchers selected 380 respondents as participants from the total population through a random purposive sampling technique. Besides, a questionnaire was used for data collection. After the data collection, the results were presented in tabulation form showing the frequency and percentage of the respondents. The results were interpreted and analyzed descriptively. The findings of the study indicated that certain linguistic barriers create problems in online teaching for learners. Among those barriers; usage of the English language, difficult terminologies of teachers, complex sentence structure, unknown jargon for learners, absence of body language, and physical absence of teachers, and strong accents of some teachers are the prominent ones. The study suggests that teachers should be properly trained in online teaching with a special focus on the aforementioned areas of difficulties.
\end{abstract}

Keywords: CALL; Linguistic barrier; MALL; Virtual learning; WhatsApp

Introduction

Communication between the speakers and listeners is one of the basic purposes of language. The main aim of language is the proper way of communicating ideas to other people. Language has to fulfill this purpose in any situation. Whenever language fails to comply with the given aim, it is said language barriers have come up in their way. Language has paramount importance in teaching-learning. According to Baran, Correia, and Thompson (2013), different language barriers stop communication between speakers and listeners. Language-related barriers always create great hindrances in teachinglearning. To put it more accurately, teaching cannot happen without the proper use of language. Sometimes, the desired goals of using language cannot be achieved due to language barriers; these are hurdles and obstacles in the way of communication. To understand the lesson properly, language barriers should be minimized to a great extent for the learners. These barriers include the usage of the English language; difficult terminologies of teachers, complex sentence structure, no use of body language, the physical absence of teachers and the challenging ascent of teachers are the prominent ones. In face-to-face classrooms, language barriers can be addressed by teachers immediately. However, the problem becomes more gruesome and intimidating when it comes to online teaching. Since a teacher is not in front of the students to observe their facial expressions and use his body postures in conveying the message.

In the current era, online teaching has increasingly been adopted by many institutions of the world. It has almost become the last option with the world educationists after the outbreak of Covid19. As the institutions are closed around the globe due to the above-mentioned pandemic, so every country has tried to move towards online teaching in one way or the other. Meanwhile, Pakistan is no exception to such a drastic change in the educational setup. Currently, the Higher Education

* Department of English, University of Malakand, Pakistan, Email: Zaheerullah25@ gmail.com

** Department of English, University of Malakand, Pakistan, Email: shaukat1443all@gmail.com

*** Department of English, University of Malakand, Pakistan, Email: sadam.khan10022@gmail.com 
Commission (HEC) of Pakistan notified all the universities to start online teaching Sethi and Sethi and Aamir (2020).

To save the precious time of students and carry on the teaching-learning process of students, the University of Malakand has also started online teaching. Faculty members are directed to adopt any feasible method with online teaching to teach their students. In such a scenario, the majority of the teachers are teaching with voice notes/audio-clips to their students. Most of the teachers adopted WhatsApp, a mobile app for online teaching. When teachers are not involved in face-to-face sessions, there occur some linguistic barriers in teaching. So, this research study aimed to find out linguistic barriers in online teaching at the undergraduate level at the University of Malakand.

\section{Literature Review}

Online teaching and learning are not yet properly and clearly defined but it is associated with any sort of teaching that has been facilitated and supported by information technology (Bärwald, 2009). Similarly, online teaching and learning normally refer to Internet-based learning, e-Learning, webbased training, web-based instruction, cyberlearning, virtual learning, and so on (Urdan \& Weggen, 2000). With the rapid advancement of technology, face-to-face teaching shifted to the virtual mode of learning. Internet is the stimulating force behind online teaching. Consequently, technology has improved and facilitated the teaching and learning process in several ways. Several online tools facilitate online teaching. Such tools are; Google Classroom, Google Meet, Zoom App, YouTube channels, learning blogs and websites, different mobile apps, and many more(Beatty, 2013). All these tools are used to teach in a better and more effective way.

Different tools can be used for online teaching. The term which is used for these technologies is CALL. It stands for Computer-Assisted Language Learning. CALL is the combination of technologies used for creativity, enhancing collaboration through the use of social networking (Kukulska-Hulme, 2009). Similarly, MALL means Mobile-Assisted Language Learning (Beatty, 2013). The latter one is the latest form of technology. There are various tools and Apps in mobile phones which are used for learning purposes. These tools are available on the mobile phone as well. An app is a short form of application software. There are numerous apps available for communications and English language learning. WhatsApp is one of the mobile apps which are available for communication. WhatsApp is an application available on the new version of Mobile phones such as; android, iPhone, Blackberry, and Nokia phones (Alsaleem, 2013, Gadwin \& Jones, 2011). Interestingly, this app can be used for sending text, voice, and video messages. It is an easier and simpler application that naive students can also use without much difficulty (Dearstyne, 2011).

There is a general agreement that students learn better when they understand the teachers' instruction. Since teaching happens through proper instructions of the teacher; whether it is virtual teaching or face-to-face teaching but teacher's instruction plays a key role. Such instruction is given through language (Huang, Liao \& Chen, 2014). Undoubtedly, language and communication are fundamental pillars of any teaching-learning process. Eventually, the importance of language and communication further increased in online teaching. Communication is the sole source behind online teaching which makes it more productive and successful. However, some language barriers disrupt the process of communication and diminish the worth of online teaching. Language barriers are hindrances in way of communication. When the message is not conveyed across to listeners due to language deficiency is called linguistic barriers. Hence, linguistics barriers often occur when the learners are not accustomed to technology and online teaching. The more they are exposed to technology, the more they can optimize their understanding. Similarly, when the teachers are not used to online teaching barriers occur (Muhlenberg \& Berge, 2005).

There can be different kinds of barriers to effective communication, such as; physical, psychological, emotional, and linguistic. Among them, linguistic barriers are closely related to online teaching in general and English language teaching in particular (Noom-Ura, 2013). Language-related barriers are often the main hurdles and obstacles in properly delivering and imparting knowledge to students in the classroom. This research paper specifically tries to highlight those essential linguistic barriers which students come across in online teaching-learning.

\section{Theoretical Framework}

This research study is linked with the Connectivism Theory. Connectivism theory illustrates that teaching-learning is no more individual activity, but rather to be connected with others in this digital era to fully exploit it. According to Seimon (2004), Connectivism is a theory for the digital age 
(Goldie, 2016) and its applications are far-reaching. So, this study is based on online teaching which considers various other online tools for teaching-learning. Moreover, the importance of this theory is increasing day by day as teaching-learning shifted towards the virtual teaching-learning process (Kop \& Hill, 2008).

\section{Statement of the Problem}

Teaching online is quite different than face to face teaching. It needs more effort on the part of teachers to teach online in an effective way. There are certain situations where it becomes more demanding and difficult to teach online. One of the challenges is linguistic barriers which often occur in the online teaching-learning process. Linguistic barriers can be a real impediment in online teaching. This research study aimed to find out all those linguistic barriers which occur at the undergraduate level in the University of Malakand.

\section{Methodology}

The physical scope of this research is the University of Malakand. There are almost thirty disciplines that offer graduate and post-graduate programs. With the outbreak of the Covid-19 Pandemic in the world, the University switched over to virtual teaching. The teachers were given free choice to use any convenient online tool for teaching-learning. The majority of teachers adopted Mobile WhatsApp as their tool for online teaching since the majority of students were not used to other online tools. It is an easier learning tool for learners to use for teaching and learning purposes. Teachers started teaching with the help of WhatsApp through voice notes and sharing materials. As the teacher was not employing face to face teaching method, there was always a threat of barriers in communication, particularly linguistic barriers.

The population of this research study was the undergraduate students of the University of Malakand of various departments. For this research, 10 departments of the university were selected, and from each of the 38 students were taken as respondents. Names of the departments are; English, Political Science, Law, Sociology, Computer Science, Zoology, Botany, Social work, Management Sciences, and Psychology. From the whole population, 380 students were considered as respondents through the random purposive sampling technique. This sampling size was taken through the Research Advisors' (2006) sampling size. It constructed a 95\% confidence interval with a Margin of Error of about $\pm 4.4 \%$ (for large populations). Moreover, the respondents' age ranged from 19 years to 23 years. Data was collected from the respondents through a questionnaire. In addition to that, the online survey method was used for data collection from the respondents. Afterward, the data were analyzed through frequencies and percentages.

\section{Results and Discussion}

The results of the collected data are given in the following Table 1. The frequency and percentage of the respondents' responses are given in Table 1. Further illustration and explanation of the results are given in the descriptive analysis of the table.

\section{Table.1Respondents' Responses in Percentages and Frequencies}

\begin{tabular}{|c|c|c|c|c|c|}
\hline S.NO & Statement & $\begin{array}{l}\text { Yes } \\
(\%)\end{array}$ & $\begin{array}{l}\text { N0 } \\
(\%)\end{array}$ & $\begin{array}{l}\text { Uncertain } \\
(\%)\end{array}$ & Total $(\%)$ \\
\hline 1 & $\begin{array}{l}\text { The usage of the English language makes it } \\
\text { difficult for me to understand the online } \\
\text { lectures. }\end{array}$ & $200(52.63)$ & $130(34.21)$ & $50(13.15)$ & $380(100)$ \\
\hline 2 & $\begin{array}{l}\text { During online lectures, teachers use difficult } \\
\text { words and terminologies which I do not } \\
\text { understand. }\end{array}$ & $210(55.26)$ & $100(26.31)$ & $70(18.42)$ & $380(100)$ \\
\hline 3 & $\begin{array}{l}\text { The teacher's speech is not very clear to be } \\
\text { understood during the online lectures. }\end{array}$ & $180(47.36)$ & $140(36.84)$ & $60(15.78)$ & $380(100)$ \\
\hline 4 & $\begin{array}{l}\text { The teacher uses various jargon and words } \\
\text { which are beyond my understanding. }\end{array}$ & $190(50)$ & $180(47.36)$ & $10(2.63)$ & $380(100)$ \\
\hline 5 & $\begin{array}{l}\text { I have less vocabulary to understand the } \\
\text { complete sentences of the teachers during } \\
\text { online lectures. }\end{array}$ & $190(50)$ & $170(44.73)$ & $20(5.26)$ & $380(100)$ \\
\hline 6 & $\begin{array}{l}\text { My teacher always uses complex sentences } \\
\text { during online lectures. }\end{array}$ & $220(57.89)$ & $130(34.21)$ & $30(7.89)$ & $380(100)$ \\
\hline 7 & $\begin{array}{l}\text { When body language is not involved, it } \\
\text { becomes difficult to properly comprehend my } \\
\text { teacher. }\end{array}$ & $330(86.8)$ & $40(10.52)$ & $10(2.63)$ & $380(100)$ \\
\hline
\end{tabular}




\begin{tabular}{llllll}
\hline \hline $\mathbf{8}$ & $\begin{array}{l}\text { Behind the screen, teaching is also challenging } \\
\text { for me to understand. }\end{array}$ & $330(86.8)$ & $40(10.52)$ & $10(2.63)$ & $380(100)$ \\
$\mathbf{9}$ & $\begin{array}{l}\text { I can understand the spoken text/voice notes } \\
\text { of my teacher. }\end{array}$ & $160(42.10)$ & $140(36.84)$ & $80(21.05)$ & $380(100)$ \\
$\mathbf{1 0}$ & $\begin{array}{l}\text { I can understand written texts and messages } \\
\text { easily. }\end{array}$ & $260(68.42)$ & $80(21.05)$ & $40(11.02)$ & $380(100)$ \\
$\mathbf{1 1}$ & $\begin{array}{l}\text { I cannot properly understand the voice notes } \\
\text { of my teachers. }\end{array}$ & $150(39.47)$ & $190(50)$ & $40(10.52)$ & $380(100)$ \\
$\mathbf{1 2}$ & $\begin{array}{l}\text { The accent of my teachers also makes it } \\
\text { difficult to understand the online lectures. }\end{array}$ & $190(50)$ & $130(34.21)$ & $60(15.78)$ & $380(100)$ \\
\hline
\end{tabular}

Table 1 illustrates all the essential linguistics barriers of the student in the online learning process. These are some of the fundamental language-related hurdles that students faced in online teaching-learning. So, in the given table, 52 percent of the respondents responded positively that the usage of the English language makes it difficult for them to understand the English language. The frequency value becomes 200 respondents out of the 380. In the same way, 130 respondents responded with no. It makes $34.21 \%$ of the responses. Similarly, 50 of the respondents showed uncertainty. It makes $13.15 \%$ of the sampling size. So, it is inferred that the majority of the participants said they have problems in understanding of English language. It can be claimed that the English language is one of the main hurdles for learners in online teaching since they rarely understand English. As Hani (2014) opines that in online teaching understanding English is always a serious problem for learners. It is always challenging for learners, with low proficiency, to understand the lectures of their teachers.

Furthermore, $55.63 \%$ of the respondents replied that during online lectures teachers use difficult terminologies and words. It makes 210 of the frequency level. While $26 \%$ of the respondents replied with No; it means they do not have any problems with teachers' diction. Similarly, $18 \%$ showed uncertainty in this regard. To draw the results, it is clearly shown that the majority of the respondents do not understand the difficult words and terminologies of the teachers in online teaching. This can be another major obstacle in delivering online teaching. This is one of the drawbacks of online teaching where students hardly ask about the explanation of challenging terminologies during the class. Another major obstacle is the teachers' speech in online teaching. Sometimes, it is also very challenging to understand the speech of the teachers. In the above table, at frequency level 180 students responded positively about teachers' speech problems. So, $47.36 \%$ of the respondents said they faced problems in understanding their teachers' speech, as it was not much clear during teaching. While, 140 of the respondents, which $36.84 \%$ of the sampling size responded that they have no issue in grasping their teachers' speech. Similarly, 60 respondents, which makes $15.78 \%$ of the total sampling said they are uncertain about it. So, this huge number of participants said they face problems in understanding the speech of their teachers. It shows that teachers' speech is not clear; either due to technical problems or their style of expression. Mahadeo (2006) states that no clarity in speech is another very serious hurdle in online teaching. It is mandatory to highlight this issue in the online teaching-learning process. Teachers must ensure clarity in their speech before switching to virtual teaching.

In the same way, the language of the teacher always plays an important role. Sometimes, teachers use various jargons and vocabulary items that are beyond the level of the students. In the table.1, 50\% of the respondents stated their teachers used certain jargon and words which they could not understand. While $47.36 \%$ of the respondents negated the above statement which implies they could understand their teachers' jargon. Though $18 \%$ of the respondents showed uncertainty in this case, still the majority of them favored the statement. At frequency level, 190 participants favored, 180 participants negated and 70 were uncertain in this regard. It suggests that still enough proportion of the respondents claim that teachers' language creates hurdles for the students in online teaching.

Moreover, students' lack of knowledge of the English language also makes problems for them in understanding online lectures. In the above table, 190 respondents which are $50 \%$ of the sampling size, state that they have less vocabulary at their disposal to understand their teachers. Sometimes, they could not pick the whole sentences of their teachers. On the other hand, $44 \%$ of the respondents said no to the above statement and 5\% showed uncertainty regarding it. So, it means that still, the majority of the respondents have less vocabulary and competency of English language to understand their teacher. A study conducted by Khan, Radzuan, Shahbaz, Ibrahim, and Mustafa (2018) said that 
vocabulary is extremely important for their learners in better understanding of the English language. Resultantly, the lack of the vocabulary of learners in this context creates further obstacles in understanding the lectures. Similarly, in the given table, teachers' usage of the structure is also observed. There are some teachers which use complex and intricate sentence structure that creates an obstacle for learners in understanding the lectures. In the above.1, 57\% of the respondents stated that their teachers always used complex sentences in online teaching. While $35 \%$ stated that it is not complex and $8 \%$ of the respondents were uncertain about it. It is inferred that enough number of the respondents perceived their teacher sentences as complex ones.

Another very crucial factor that makes the teaching-learning process easier is the use of body language in the classroom. In the above table, $86 \%$ of the respondents say it is very difficult for them to understand their teachers when body language is not involved. It suggests the body language and gestures play a huge role in grabbing the attention of the learners and imparting knowledge in a better way. On the other hand, $10 \%$ of the respondents negated the above statement and $2 \%$ were uncertain about it. This massive response in favor of body language in the classroom suggests that here students are more accustomed to face-to-face teaching. Tai (2014) illustrates that body language plays a significant role in the proper delivery of lectures. She deemed it one of the prerequisites of language teaching. So, it is a great hurdle for them in understanding the online lectures when body language is not involved in delivering lectures.

When a teacher is present in the class and delivers lectures through audio, it further makes understanding challenging for the learners. In the above table, $86 \%$ of the respondents say that it is a problem for them to understand behind the screen. While just $10 \%$ of the respondents say they have no problem with that. This huge difference is connected with the idea of the use of body language. Mostly, here teachers delivered their lectures through voice notes and no physical appearance and facial expressions were involved in it. So, again it demonstrates that the presence of a teacher in the class has vital importance in the teaching-learning process. It illustrates that when a teacher is not in front of the students, so that creates linguistic barriers for the learners. Students cannot properly comprehend their teachers in such situations.

There is also a problem in the understanding of the written and spoken text. Some learners can better understand spoken words, while others are better in written text. It also creates an obstacle for the learners in online teaching. The majority of the respondents say that can understand written text and messages better than spoken text. In the above table, 260 of the respondents, that become $68 \%$ of the total, showed they can understand written text, while 160 of the respondents which are $42 \%$ of the total, showed they can understand spoken texts as well. This is a clear difference between written and spoken text. So, again it is a hurdle for the learners in online teaching when they often get their lectures in spoken language and rarely get through written text. Apart from that accent of the teachers also play a pivotal role in imparting the knowledge. In the above table, $50 \%$ of the respondents face problems in understanding their teachers' accents. On the other hand, 34\% of the respondents do not face any problem with their teachers' accents and 16\% of the respondents showed uncertainty. It means half of the respondents do face problems in their teachers' accents which is a serious obstacle for them. Simply, these are all some of the major linguistic barriers in the online teaching-learning process which the students of the University of Malakand came across. These barriers should be addressed appropriately when switching to virtual teaching. It needs collective efforts to handle them but mostly at an individual level since most of the obstacles are concerned with an individual way of teaching.

\section{Conclusion and Recommendations}

This research paper aimed to focus on those linguistic barriers which come across in online teaching at the undergraduate level at the University of Malakand. The study found there are certain linguistic barriers in online teaching for learners which make it difficult for them to properly understand the lectures. Among those barriers, usage of the English language, difficult terminologies of teachers, complex sentence structure, no use of body language, the physical absence of teachers, and the challenging ascent of teachers are the prominent ones. So, the majority of the students stated they had faced the above language problems in their online classes. Most teachers used WhatsApp Mobile for teaching their students. And these problems and barriers were found in their online classes. It is recommended that such barriers should be minimized while switching the mode of teaching from face-to-face to virtual. Teachers should consult various means and online tools to reduce the chances 
of linguistic barriers for better outcomes for learners. More importance should be given to interactive online classrooms where students also take part in the teaching-learning process. The better use of technology and facilitation of learners can bring a positive change in online teaching. Simply, these hurdles and obstacles will be overcome with the effective strategies of teachers and appropriate use of technology.

However, this research study has certain limitations which may affect the worth of the study. First of all, the researchers limited this research to one university. The results might be different if applied to many universities of the province or country. It has time restraints as well. The scenario created by Covid-19 can be another obstacle in this research study. Due to Covid-19, every member of the society was in a stressful and tense situation. Nevertheless, further studies can be conducted to improve the quality of online teaching. Research is feasible to check the trauma of covid-19 in online teaching and its impacts on students. In the same way, students' perceptions about online teaching and face-to-face teaching can be investigated to know about their preferences. Finally, it is worthy to conduct a study on students' and teachers' collaboration during online teaching in the time of Covid19, whether they faced some other problems apart from linguistic barriers or not. Such studies can be helpful to cope with the situation inflicted upon our education in general in Pakistan particular.

\section{References}

Alsaleem, B. I. A. (2013). The effect of" WhatsApp" electronic dialogue journaling on improving writing vocabulary word choice and voice of EFL undergraduate Saudi students. Arab World English Journal, 4(3), 213-225.

Bärwald, W. (2009). Expert practice lexicon communication technologies: networks-services applications. Expert publisher.

Beatty, K. (2013). Teaching \& researching: Computer-assisted language learning. Routledge.

Baran, E., Correia, A. P., \& Thompson, A. (2013). Tracing successful online teaching in higher education: Voices of exemplary online teachers. Teachers College Record, 115(3), 1-41.

Dearstyne, B. W. (2011). Smartphones: The new information revolution. The Information Management Journal, 39(4). 38-44.

Godwin-Jones, R. (2011).Mobile Apps for Language Learning. Language Learning \&Technology, 15(2), $2-11$.

Goldie, J. G. S. (2016). Connectivism: A knowledge learning theory for the digital age? Medical Teacher, 38(10), 1064-1069.

Hani, N. A. B. (2014). Benefits and barriers of computer-assisted language learning and teaching in the Arab world: Jordan as a model. Theory and Practice in Language Studies, 4(8), 1609-1615

Sethi, B. A., Sethi, A., Ali, S., \& Aamir, H. S. (2020). Impact of Coronavirus disease (COVID-19) pandemic on health professionals. Pakistan Journal of Medical Sciences, 36(COVID19-S4), S6.

Huang, Y. M., Liao, Y. W., Huang, S. H., \& Chen, H. C. (2014). A Jigsaw-based Cooperative Learning Approach to Improve Learning Outcomes for Mobile Situated Learning. Educational Technology \& Society, 17(1), 128-140.

Khan, R. M. I., Radzuan, N. R. M., Shahbaz, M., Ibrahim, A. H., \& Mustafa, G. (2018). The role of vocabulary knowledge in speaking development of Saudi EFL learners. Arab World English Journal (AWEJ) Volume, 9(1), 406-418

Kop, R., \& Hill, A. (2008). Connectivism: Learning theory of the future or vestige of the past? The International Review of Research in Open and Distributed Learning, 9(3), 1-13

Kukulska-Hulme, A. (2009). Will mobile learning change language learning? ReCALL, 21(2), 157-165.

Mahadeo, S. K. (2006). English language teaching in Mauritius: A need for clarity of vision regarding English language policy. The International Journal of Language, Society, and Culture, 18, 18-2.

Muilenburg, L. Y., \& Berge, Z. L. (2005). Student barriers to online learning: A factor analytic study. Distance education, 26(1), 29-48.

Noom-Ura, S. (2013). English-Teaching Problems in Thailand and Thai Teachers' Professional Development Needs. English Language Teaching, 6(11), 139-147.

Siemens, G. (2004). Connectivism: A Learning Theory for the Digital Age. Elearnspace http://www.elearnspace.org/Articles/connectivism.htm

Tai, Y. (2014). The application of body language in English teaching. Journal of Language Teaching and Research, 5(5), 1205.

Urdan, T. A., \& Weggen, C. C. (2000). Corporate e-learning: Exploring a new frontier. San Francisco, CA: WR Hambrecht Co. 